\title{
PEMBUATAN PULP DENGAN MEMANFAATKAN LIMBAH KULIT DURIAN (DURIO ZIBETHINUS MURR) DENGAN CAMPURAN (RESINA COLOPHONIUM) GUNA MENCEGAH DEGRADASI LINGKUNGAN
}

\author{
Deddy Kurniawan W, Fahmi Arifan, M. Dwi Khoirun Adim \\ Program Studi Diploma III Teknik Kimia \\ Fakultas Teknik Universitas Diponegoro \\ Email: deddy_kurniawan52@yahoo.com; fahmiarifan@gmail.com
}

\begin{abstract}
Deddy Kurniawan W, Fahmi Arifan, M. Dwi Khoirun Adim, in this article explain that paper is one of the primary needs for humans today. High paper usage is resulting increased in production of paper. On the other hand, paper which are usually made from cellulose and hemi-cellulose in wood can result environmental degradation, due to the use of wood and tree felling leads to long-term basis that can increase the temperature of the earth surface (global warming). Durian is relatively abundant in Indonesia, durian shell contains high cellulose ( 50-60\%) and lignin content ( $5 \%$ ), also a low starch content ( $5 \%$ ). Durian shell wastes containing fibre with dimensions of length and fiber thick wall that be able to bind well when given a synthetic adhesive or an adhesive mineral. Pulp which is produced from durian shell waste in experiments were $1,2,3$ and 4, have a value of $\alpha$ - cellulose content of $35 \%, 45 \%, 27.7 \%, 37.5 \%$ and $57.6 \%$, respectively. When yield value of $49.2 \%, 66.8 \%$ and $48.2 \%$ respectively.
\end{abstract}

Keywords: pulp, durian, gondorukem, digester

\section{PENDAHULUAN}

Kertas merupakan salah satu kebutuhan primer bagi manusia saat ini. Penggunaan kertas yang tinggi mengakibatkan pemicu peningkatan produksi kertas. Dilain pihak kertas yang biasanya terbuat dari selulosa dan hemiselulosa pada kayu pohon dapat mengakibatkan degradasi lingkungan, karena penggunaan kayu mengarah pada penebangan pohon dan secara jangka panjang dapat meningkatkan suhu bumi secara keseluruhan (global warming) selain itu pula pohon juga menjadi salah satu solusi penanggulangan global warming karena dapat menyerap gas $\mathrm{CO}_{2}$. Untuk itu perlu adanya bahan baku alternatif untuk pembuatan kertas sebagai inovasi dan wujud pencegahan terjadinya degradasi lingkungan dengan penggunaan kayu yang berlebihan dari pohon. Untuk menghasilkan 1 ton pulp sebagai bahan baku kertas diperlukan 4,5 $\mathrm{m}^{3}$ kayu bulat, maka industri pulp di Indonesia pada tahun 1999 memerlukan 24 juta $\mathrm{m}^{3}$ kayu bulat. Dengan asumsi potensi kayu bulat pada areal hutan konversi ratarata $80 \mathrm{~m}^{3}$ per hektar, maka untuk memenuhi kebutuhan bahan baku industri pulp harus ditebang sekitar 300.000 ha hutan alam. Areal hutan alam yang dirusak dengan tebang habis akan semakin bertambah seiring dengan bertambahnya kapasistas industri pulp dan kertas, sementararealisasitanamanHTI-

pulpmasihsekitar $20 \%$

(http://repository.mb.ipb.ac.id/6/5/mbipb-

12312421421421412-achmadfach-955-5-dmb2-05-n.pdf; Suyadi, 2008; Nurulhuda, 2008)

Produksi durian di Indonesia cukup melimpah. Data Biro Pusat Statistik (2004), menunjukkan bahwa produksi durian meningkat setiap tahun. Seiring dengan meningkatnya luas daerah panen durian yaitu dari 24.031 ha pada tahun 1999 menjadi 53.770 ha pada tahun 2003, maka terjadi peningkatan produksi durian di Indonesia dari 194.359 ton pada tahun 1999 menjadi 741.841 ton pada tahun 2002 (Sugiyono, 2009). Sedangkan di wilayah Semarang vegetasi tanaman durian dapat dijumpai di daerah Kecamatan Tembalang, Banyumanik, Gunung Pati, Ngaliyan dan Mijen, dengan jumlah lebih dari 100.000 pohon dan tingkat produksi $1500-2000$ ton/tahun.

Hasil penelitian menunjukkan, kulit durian secara proporsional mengandung unsur selulose yang tinggi $(50-60 \%)$ dan kandungan lignin $(5 \%)$ serta kandungan pati yang rendah $(5 \%)$ sehingga dapat diindikasikan bahan tersebut bisa digunakan sebagai campuran bahan baku pangan olahan serta produk lainnya yang dimanfaatkan. Selain itu, limbah kulit durian mengandung sel serabut dengan dimensi yang panjang serta dinding serabut yang cukup tebal sehingga akan mampu berikatan dengan baik apabila diberi bahan perekat sintetis atau bahan perekat mineral (Nasution, 2010).

Limbah kulit durian dapat menjadi alternatif dalam pembuatan pulp untuk pembuatan kertas, selama ini penggunaan bahan baku pembuatan kertas masih menggunakan kayu sebagai bahan utama. Perilaku ini akan mengurangi jumlah pohon sebagai keseimbangan ekosistem yang habis sebagai bahan baku pembuatan kertas. Sedangkan kulit durian masih belum termanfaatkan secara masikmal dan hanya dibuang begitu saja. 


\section{Perumusan Masalah}

Pembuat kertas dari bahan alternatif terus berkembang demi mencarikan solusi terhadap pembabatan hutan yang menjadi bahan utama dalam pembuatan kertas.Perilaku ini akan berdampak pada pemanasan global. Akan tetapi dalam semua penelitian itu belum ada penelitian yang mmanfaatkan kulit durian. Permasalahan yang dihadapi ialah bagaimana cara memaksimalkan pembuatan pulp dari kulit durian dengan variabelvariabel yang tepat sehingga dapat menghasilkan kertas yang berkualitas.

\section{Tujuan}

Tujuan dari penelitian ini yaitu mendapatkan variabel - variabel dengan kondisi maksimum dalam pembuatan pulp dari kulit durian. Sehingga dapat menghasilkan kertas dengan kualitas tinggi.

\section{Kegunaan}

Kegunaan dari penelitian ini diharapkan dapat memanfaatkan limbah kulit pisang dalam sektor home industi yaitu memberikan inovasi untuk memanfaatkan limbah kulit durian guna menaikkan nilai jual dan memanfaatkan kulit durian sebagai bahan utama pembuatan kertas dalam indutri rumahan (home industri).

\section{METODOLOGI}

\section{Rancangan Percobaan}

Dalam percobaan atau penelitian, proses pulping yang digunakan adalah proses soda, dengan pertimbangan:

- Banyak dilakukan oleh industri-industri kertas.

- Bahan baku fleksibel dan mudah didapat.

- Kekuatan pulp hasil pemasakan relatif tinggi. Pada analisa bahan dasar ampas tebu, akan dilakukan beberapa macam analisa, yaitu:

- Analisa bahan baku (kadar air, kadar abu, kadar $\alpha$ sellulosa)

- Analisa hasil pulp (kadar abu, bilangan permanganat, kadar $\alpha$ sellulosa, dan warna)

- Analisa setelah bleaching (warna)

Sedangakan percobaan yang dilakukan meliputi 2 tahap, yaitu:

- Pemasakan pulo menggunakan nitrat dan bahan tambahan gondorukem

○ Proses pemutihan (bleaching)

Variabel tetap

- $\quad$ Berat sampel : 2000 gram (kering)

- Konsentrasi larutan pemasak : $15 \%$

- Larutan pemasak : $\mathrm{NaOH} 80 \%$ berat dan $\mathrm{Na}_{2} \mathrm{CO}_{3} 20 \%$ berat.
Tabel 1. Variabel Berubah

\begin{tabular}{ccccc}
\hline & \multicolumn{2}{c}{ Variable } & Interaksi & Yield \\
\cline { 2 - 4 } Run & $\begin{array}{c}\text { T } \\
\text { (suhu) }\end{array}$ & t (waktu) & T.t & (gram) \\
\hline 1 & - & - & + & a1 \\
2 & + & - & - & a2 \\
3 & - & + & - & a3 \\
4 & + & + & - & a4 \\
\hline
\end{tabular}

Keterangan:

Kondisi operasi optimum : $80^{\circ} \mathrm{C} \pm 10^{\circ} \mathrm{C}$

Waktu : 2 jam \pm 1 jam (Prasetya, 2010)

Proses percobaan ampas tebu menjadi kertas

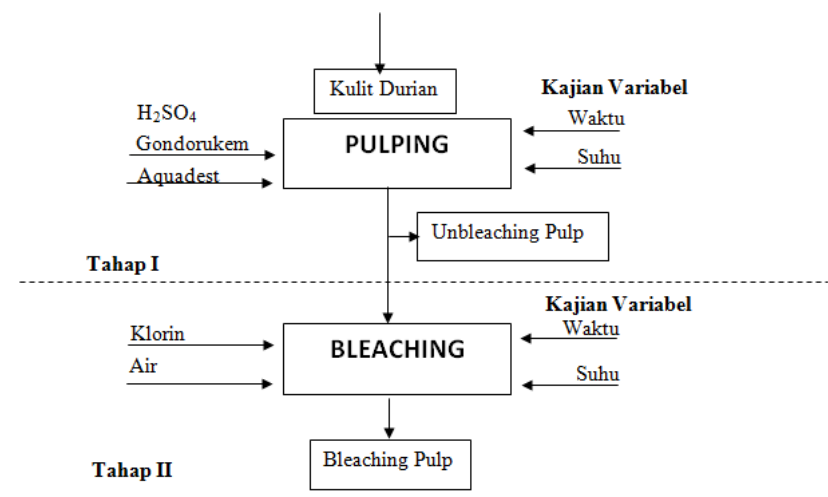

Gambar 1. Proses pembuatan pulp dari kulit durian (Khoir, 2011)

\section{HASIL DAN PEMBAHASAN}

\section{Hasil analisa Kadar a Sellulosa dan Yield}

Penelitian ini adalah dapat mengetahui sumber alternatif dalam proses pulping dalam proses pembuatan kertas. Selain itu dapat diketahui variabel yang paling berpengaruh dalam proses pulping untuk pembuatan kertas. Beberapa parameter yang diteliti adalah suhu dan lama proses dalam digester, hingga didapatkan operasi optimum menggunakan factorial design.

Uji analisa kandungan produk menggunakan sejumlah sampel yang diambil setiap run yang dilakukan sesuai variabel. Sampel berupa hasil pulp kulit durian. Dari tiap variabel di analisa kasar $\alpha$ selulosa.

Dari hasil tabel 2 didapatkan hasil optimal pada percobaan kedua untuk dibuat menjadi pulp. Dengan suhu $160^{\circ} \mathrm{C}$ dan waktu pemasakan selama 2 jam didapatkan nilai $\alpha$ - sellulosa mencapai $45 \%$ dan yield $49 \%$.

Dari data diatas menunjukkan pemsakan yang terlalu lama menimbulkan efek yang tidak baik pada proses pemasakan pulp, mungkin yang terjadi malahan bahan terlalu matang dan serat tidak saling berikatan. 
Tabel 2. Hasil Percobaan untuk nilai kadar sellulosa dan nilai yield dari pulp

\begin{tabular}{cccccc}
\hline Percobaan & $\begin{array}{c}\text { Berat Kulit } \\
\text { Durian }\end{array}$ & $\begin{array}{c}\text { Suhu } \\
\left(\mathbf{o}_{\mathbf{c}}\right)\end{array}$ & $\begin{array}{c}\text { Waktu } \\
(\text { Jam })\end{array}$ & $\begin{array}{c}\text { Kadar A } \\
\text { Sellulosa }\end{array}$ & Yield \\
\hline 1 & $500 \mathrm{gr}$ & 150 & 2 & $35 \%$ & $57,6 \%$ \\
2 & $500 \mathrm{gr}$ & 160 & 2 & $45 \%$ & $49,2 \%$ \\
3 & $500 \mathrm{gr}$ & 150 & 4 & $27,7 \%$ & $66,8 \%$ \\
4 & $500 \mathrm{gr}$ & 160 & 4 & $37,5 \%$ & $48,2 \%$ \\
\hline
\end{tabular}

\section{KESIMPULAN}

Kulit durian yang selama ini hanya dibuang dan belum ada pengolahan lebih lanjut memang dapat diolah menjadi pulp sebagai bahan utama pembuatan kertas. Dan pulp yang dihasilkan sangat baik. Variabel optimal yang diperoleh guna mendapatkan pulp yang baik untuk bahan utama pembuatan kertas adalah variabel ke 2 dengan berat durian 500gr, suhu $160 \mathrm{oC}$, dan waktu pemasakan 2 jam menghasilkan nilai $\alpha$ sellulosa sebesar $45 \%$ dan yield $49,2 \%$. Dari nilai yang dihasilkan diatas kulit durian dapat dipakai dalam bahan baku pulp guna pembuatan kertas.

\section{DAFTAR PUSTAKA}

1. Anonim. 2004. Biro Pusat Statistika, Produksi Durian di Indonesia, http://repository.mb.ipb.ac.id/6/5/mbipb12312421421421412-achmadfach-955-5dmb2-05--n.pdf

2. Khoir, Muhammad. 2011. Cara Pembuatan Kertas, Bogor. Institut Pertanian Bogor
3. Nasution, Zainal Abidin. 2010. Pembuatan dan Karakterisasi Kertas dari Limbah Jerami Padi Untuk Tatakan Gelas Cetak Tangan. Medan. Balai Riset dan Standardisasi Industri Medan.

4. Prasetya, Bambang. 2010. Pemanfaatan Biomassa Lignoselulosa Ampas Tebu Untuk Produksi Bioetanol. Bogor . Institut Pertanian Bogor.

5. Sugiyono, Agus. 2009. Penggunaan energi di industri pulp dan kertas: aspek Teknologi dan lingkungan, Badan Pengkajian dan Penerapan Teknologi, Jakarta.

6. Suyadi, Daman. 2008. Penggunaan Biji Jarak dan Gondorukem Sebagai Nyala Awal Untuk Briket Semi Kokas Kota Bangun Kalimantan Timur. Bandung. Puslitbang LIPI Bandung.

7. Nurulhuda, 2008. Penghasilan kertas daripada pulpa Kenaf: kesan pemukulan dan pengadunan Gentian, Bogor. Institut Pertanian Bogor. 